\title{
Control of Bacterial Seedling Rot of Rice by Avirulent Strains of Pseudomonas glumae*
}

\author{
Naruto FurUYA**,Tomoko OKAMOTO***, Yuichi KoRI**, \\ Nobuaki MatsuYAMA** and Satoshi WaKıмото**
}

\begin{abstract}
The treatment of rice seeds with avirulent strains of Pseudomonas glumae significantly suppressed the incidence of bacterial seedling rot of rice caused by virulent strains. The suppression varied depending on the combinations of the avirulent and virulent strains used. The remarkable suppression resulted by the use of high concentration $\left(\mathrm{ca} \cdot 10^{10} \mathrm{cfu} / \mathrm{ml}\right)$ of avirulent strains for pre-treatment. The killed cells of avirulent strain of $P$. glumae or other bacteria belonging to the genus Agrobacterium, Erwinia, Bacillus and Clavibacter tested did not suppress disease incidence. Of five avirulent strains of $P$. glumae used, avirulent strain N7503 was the highest in the suppression to the disease incited by virulent strains. Avirulent strain N7503 may be useful agent for biocontrol of bacterial seedling rot of rice.
\end{abstract}

(Received October 2, 1990)

Key words: Pseudomonas glumae, bacterial seedling rot of rice, avirulent strain, biological control.

\section{INTRODUCTION}

Pseudomonas glumae Kurita et Tabei 1967, the causal bacterium of grain rot of rice is widely distributed not only in Japan but also in Korea and China causing serious losses in rice production $^{10,11)}$. The bacterium also incites bacterial seedling rot of rice in Japan where the seedlings are grown in nursery boxes under high humidity and temperature conditions. For control of the bacterial grain rot or seedling rot of rice, some measures such as seed or soil disinfection by chemicals have been recommended ${ }^{7,8,13}$. Since the effect of these practices, however, was not enough and not economical, some feasible methods have been requested to be developed.

Recently, the studies on biological method to control bacterial diseases of plant have been emphasized. Biocontrol potential may offer clues to many persistent problems in agriculture including over-reliance on agricultural chemicals and pollutions caused by chemical application.

Actually, avirulent bacteriocin producing strains of $P$. solanacearum and Agrobacterium tumefaciens have been successfully applied to control bacterial wilt of solanaceous plants caused by $P$. solanacearum ${ }^{2,3,9)}$ and crown gall of various dicotyledonous plants caused by $A$. tumefaciens $^{5,6}$, respectively. In this paper, we report the suppressiveness of avirulent $P$. glumae strains to bacterial seedling rot of rice and its mechanisms.

\footnotetext{
* This work was supported by a Grant-in-Aid for Scientific Research No. 01440008 (1989).

** Faculty of Agriculture, Kyushu University, Fukuoka 812, Japan 九州大学農学部

*** Present address: CSK Co. Ltd., Fukuoka 812, Japan 現在: CSK (侏)
} 


\section{MATERIALS AND METHODS}

Bacterial strains. Strains of $P$. glumae used were described previously ${ }^{12)}$. Many strains of $P$. glumae collected from various localities of Japan and preserved in the Laboratory of Plant Pathology, Kyushu University, were considerably different in pathogenicity, i.e., some strains maintained strong pathogenicity, while others lost during preservation. The suppressiveness of avirulent strains of $P$. glumae to bacterial seedling rot of rice by seed treatment was tested. Six phytopathogenic and saprophytic bacteria, viz. Agrobacterium tumefaciens Ku7411, Erwinia carotovora subsp. carotovora N7129, Clavibacter michiganensis subsp. michiganensis N6601, Bacillus subtilis ATCC 6633, $P$. syringae pv. syringae I and $P$. fluorescens p-15 besides $P$. glumae strains were also tested for their suppressiveness. These bateria had been preserved under freeze-dried conditions in the Laboratory of Plant Pathology, Kyushu University. All of the bacterial strains were preliminary cultured on the slants of YPDA medium (yeast peptone dextrose agar medium: yeast extract $3 \mathrm{~g}$, peptone $0.6 \mathrm{~g}$, dextrose $3 \mathrm{~g}$, agar $15 \mathrm{~g}$, distilled water 1 liter, $\mathrm{pH} \mathrm{7.2)} \mathrm{at} 30^{\circ} \mathrm{C}$ for $48 \mathrm{hr}$. The bacterial cells were suspended in sterile distilled water. A ten $\mathrm{ml}$ of the suspension was added to $200 \mathrm{ml}$ of YPD broth in Sakaguchi flask and shaked at $30^{\circ} \mathrm{C}$ for $48 \mathrm{hr}$. The bacterial cells were harvested by centrifugation at $6,000 \times g$ for $20 \mathrm{~min}$, and resuspended in sterile distilled water. Viable cells were counted by plating on YPDA medium. The bacterial suspensions thus prepared were used for pre-treatment or as inoculum.

Killed bacterial cells. For preparing killed bacterial cells, heat-treatment, chloroform treatment and UV irradiation were applied. To kill the bacterial cells by heat, a $20 \mathrm{ml}$ of avirulent strain $\mathrm{N} 7503$ (conc. $1.4 \times 10^{9} \mathrm{cfu} / \mathrm{ml}$ ) was boiled at $100^{\circ} \mathrm{C}$ for $15 \mathrm{~min}$ in water bath. Chloroform treatment was carried out as follows: A $30 \mathrm{ml}$ of the bacterial suspension in a $500-\mathrm{ml}$ beaker was placed in a 2,000-ml beaker containing $100 \mathrm{ml}$ of chloroform, which was covered with aluminum foil, and the suspension was exposed to chloroform vapor under gentle shaking for $4 \mathrm{hr}$. A five $\mathrm{ml}$ of the suspension was taken in petri dish $(9 \mathrm{~cm}$ in diameter) and irradiated by UV (TOSHIBA GL 15) from the distance of $30 \mathrm{~cm}$ for $4 \mathrm{hr}$.

Rice Seeds. The seeds of rice cultivar Asominori were used. The seeds were disinfected with $3 \%$ hypochlorite solution (Antiformin) at room temperature for $90 \mathrm{~min}$ and washed with running tap water for $30 \mathrm{~min}$.

Bacterization. Seeds were treated with bacteria as follows: Rice seeds were dipped in the suspension of avirulent strain containing $1.5 \%$ methylcellulose. The seeds used as check were similarly treated with a suspension of methylcellulose. The treated seeds were sown at the density of 60 seeds per seedling cup $(60 \times 60 \times 45 \mathrm{~mm})$ containing $80 \mathrm{~g}$ of the heat-sterilized soil (Kumiai), covered with a thin-layer of the same soil, and then a $10 \mathrm{ml}$ of the bacterial suspension of virulent strain was poured as inoculum. The seedling cups were placed in a inoculation chamber at $32^{\circ} \mathrm{C}$ under high humidity for $48 \mathrm{hr}$, and moved to the growth chamber $\left(28^{\circ} \mathrm{C}\right.$, $12 \mathrm{hr}$ light/12 hr dark cycle) for greening. Soil moisture was always saturated by watering several times daily. Disease severity was evaluated with a rating scale ranging from $0-5$, where $0=$ symptomless, $5=$ complete withering. Disease severity was calculated by the following formula; $\Sigma$ (number of samples per rating $\times$ rating value) $/ 60$. Thus maximum disease severity $=5$.

\section{RESULTS}

The application of avirulent strains of $P$. glumae to rice seeds prior to inoculation with virulent strains suppressed the seedling rot with various degree depending upon the combinations of both avirulent and virulent strains of $\boldsymbol{P}$. glumae used (Table 1). The disease caused by strain Ku8111 was suppressed by avirulent strain N7503, YN7810 and 805, but not by avirulent strain N750 and YN7825. In the case of virulent strain So-1, all avirulent strains suppressed remark- 
Table 1. Suppression of bacterial seedling rot of rice by pre-treatment with avirulent strains of Pseudomonas glumae

\begin{tabular}{clc}
\hline \hline Pre-treatment a) & Inoculum ${ }^{\text {b) }}$ & Disease severity \\
\hline N7503 & So-1 & 0.2 \\
& 2 & 0.0 \\
N750 & Kyu82-34-2 & 0.2 \\
& Ku8111 & 0.9 \\
& So-1 & 0.3 \\
& 2 & 4.2 \\
YN7810 & Kyu82-34-2 & 4.8 \\
& Ku8111 & 3.4 \\
& So-1 & 0.6 \\
YN7825 & 2 & 4.6 \\
& Kyu82-34-2 & 4.8 \\
& Ku8111 & 1.2 \\
805 & So-1 & 0.3 \\
& 2 & 4.7 \\
& Kyu82-34-2 & 4.6 \\
& Ku8111 & 4.4 \\
& So-1 & 0.6 \\
Check & 2 & 0.3 \\
& Kyu82-34-2 & 4.1 \\
& Ku8111 & 1.1 \\
& So-1 & 4.9 \\
& 2 & 5.0 \\
& Kyu82-34-2 & 4.9 \\
& Ku8111 & 4.9 \\
\hline
\end{tabular}

a) Concentration; N7503: $3.8 \times 10^{10}, \mathrm{~N} 750: 7.4 \times 10^{10}$, YN7810: $3.1 \times 10^{10}$, YN7825: $2.4 \times 10^{10}, 805$ : $6.0 \times 10^{10}, \mathrm{cfu} / \mathrm{ml}$, respectively.

b) Concentration; So-1: $2.6 \times 10^{7}, 2: 0.9 \times 10^{7}$, Kyu82-34-2: $1.2 \times 10^{7}$, Ku8111: $1.3 \times 10^{7}$, cfu/g of soil, respectively.

Table 2. Suppression of bacterial seedling rot of rice at different concentrations of avirulent and virulent bacterial suspensions used for pre-treatment and inoculation, respectively

\begin{tabular}{ccc}
\hline $\begin{array}{c}\text { Avirulent strain } \\
\text { N7503 (cfu/ml) }\end{array}$ & $\begin{array}{c}\text { Virulent strain } \\
\text { So-1 (cfu/g of soil) }\end{array}$ & Disease severity \\
\hline $10^{6}$ & $10^{5}$ & 4.5 \\
$10^{6}$ & $10^{7}$ & 5.0 \\
$10^{6}$ & $10^{9}$ & 5.0 \\
$10^{8}$ & $10^{5}$ & 3.8 \\
$10^{8}$ & $10^{7}$ & 4.5 \\
$10^{8}$ & $10^{9}$ & 4.8 \\
$10^{10}$ & $10^{5}$ & 0.0 \\
$10^{10}$ & $10^{7}$ & 0.1 \\
$10^{10}$ & $10^{9}$ & 0.2 \\
- & $10^{5}$ & 4.7 \\
- & $10^{7}$ & 5.0 \\
- & $10^{9}$ & 5.0 \\
\hline
\end{tabular}


ably. When virulent strain 2 was used, disease severity was significantly reduced by avirulent strains N7503 and 805 except N750, YN7810 and YN7825. In the case of virulent strain Kyu82-34-2, only N7503 suppressed, except other four strains. The disease suppressiveness of avirulent strains was also depended upon bacterial concentrations. When rice seeds were dip-

Table 3. Comparison between biological and chemical methods in the suppression of bacterial seedling rot of rice a)

\begin{tabular}{lcc}
\hline \hline Treatment & Concentration & Disease severity \\
\hline Seeds were coated with avirulent strain N7503 & $10^{10} \mathrm{cfu} / \mathrm{ml}$ & 0.5 \\
Soil was mixed with Kasugamycin • captan WP & $0.4 \mathrm{mg} / \mathrm{g}$ of soil & 0.0 \\
Untreated & - & 4.2
\end{tabular}

a) Inoculum: Pseudomonas glumae virulent strain So-1 at the concentration of $1.9 \times 10^{7} \mathrm{cfu} / \mathrm{g}$ of soil.

Table 4. Effect of avirulent strain N7503 on the suppression of bacterial seedling rot of rice incited by virulent strains of Pseudomonas glumae

\begin{tabular}{lccccccc}
\hline \hline \multirow{2}{*}{ Seed treatment } & \multicolumn{6}{c}{ Virulent strainsa) and disease severity } \\
\cline { 2 - 7 } & Ku8106 & Ku8121 & III & 8001 & 8017 & I & Ku8105 \\
\hline N7503 b) & 0.1 & 0.1 & 0.1 & 0.3 & 0.2 & 0.3 & 0.0 \\
$1.5 \%$ methylcellulose & 4.6 & 4.2 & 3.8 & 3.6 & 4.1 & 3.9 & 3.9 \\
\hline
\end{tabular}

a) Concentration; Ku8106: 1.9 $\times 10^{7}$, Ku8121: $7.4 \times 10^{6}$, III: $2.1 \times 10^{7}, 8001: 6.1 \times 10^{6}, 8017: 1.6 \times 10^{7}$, I: $6.5 \times 10^{7}, \mathrm{Ku} 8105: 6.4 \times 10^{6}, \mathrm{cfu} / \mathrm{g}$ of soil, respectively.

b) Concentration; N7503: $4.1 \times 10^{10} \mathrm{cfu} / \mathrm{ml}$.

Table 5. Suppression of bacterial seedling rot of rice ${ }^{\text {a) }}$ by various bacteria

\begin{tabular}{lc}
\hline \hline Bacterium & Disease severity \\
\hline Agrobacterium tumefaciens Ku7411 & 5.0 \\
Erwinia carotovora subsp. carotovora N7129 & 5.0 \\
Clavibacter michiganensis subsp. michiganensis N6601 & 5.0 \\
Bacillus subtilis ATCC 6633 & 5.0 \\
Pseudomonas syringae pv. syringae I & 5.0 \\
Pseudomonas fluorescens p-15 & 5.0 \\
Pseudomonas glumae N7503 & 0.4 \\
Check (1.5\% methylcellulose) & 5.0 \\
\hline
\end{tabular}

a) Virulent strain So-1 was added to the oven-dried soil at the concentration of $3.5 \times 10^{7} \mathrm{cfu} / \mathrm{g}$ of soil.

Table 6. Suppression of bacterial seedling rot of ricea) by pre-treatment with living and killed cells of avirulent Pseudomonas glumae

\begin{tabular}{llc}
\hline \hline Strain & Seed treatment ${ }^{\mathrm{b}}$ ) & Disease severity \\
\hline $\mathrm{N} 750 \mathrm{a}^{\mathrm{c})}$ & Living bacteria & 0.0 \\
& Heated bacteria $\mathrm{d}$ ) & 4.8 \\
& UV irradiated bacteria $\mathrm{e}$ ) & 4.4 \\
& Chloroform treated bacteria $\mathrm{f}$ ) & 4.9 \\
Control & $1.5 \%$ methylcellulose & 5.0 \\
\hline
\end{tabular}

a) Soil was incorporated with So-1 $\left(3.5 \times 10^{6} \mathrm{cfu} / \mathrm{g}\right.$ of soil).

b) Rice seeds were dipped in each suspension for $24 \mathrm{hr}$ prior to sowing.

c) Concentration: $1.4 \times 10^{9} \mathrm{cfu} / \mathrm{ml}$.

d) Heat treatment at $100^{\circ} \mathrm{C}$ for $15 \mathrm{~min}$.

e) UV irradiated with TOSHIBA GL 15 at the distance of $30 \mathrm{~cm}$ for $4 \mathrm{hr}$.

f) Chloroform vapor treatment for $4 \mathrm{hr}$. 
ped in the suspension of avirulent strain N7503 at various concentrations $\left(10^{6}, 10^{8}, 10^{10} \mathrm{cfu} / \mathrm{ml}\right)$ before sowing and then inoculated with virulent strain So-1 at various concentrations $\left(10^{5}, 10^{7}\right.$, $10^{9} \mathrm{cfu} / \mathrm{g}$ of oven-dried soil), the highest disease suppression was obtained with the highest concentration of avirulent strain (Table 2). The disease suppression in this case was almost the same as that obtained by soil-treatment with Kasugamycin •captan WP at the dosage of 0.4 $\mathrm{mg} / \mathrm{g}$ dried soil (Table 3). Avirulent strain N7503 showed remarkable suppressiveness to the disease caused by virulent strains (Table 4).

Other bacteria belonging to the genus Agrobacterium, Erwinia, Clavibacter and Bacillus did not suppress bacterial seedling rot of rice (Table 5). The cells of avirulent strain N7503 killed by heat, UV irradiation or chloroform treatment also did not show any suppressiveness (Table 6).

\section{DISCUSSION}

In the previous paper ${ }^{4}$, we have reported on the suppression of the bacterial wilt of tomato by pre-treatment of the seedlings with $P$. glumae. It was exhibited not only by living cells but also by killed cells. The mechanism of suppression was suspected to be the competition of infection sites and induced resistance. It was confirmed in this experiment that the bacterial seedling rot of rice was also suppressed by pre-treatment with avirulent strains of P. glumae. However, the suppression in this case was extremely varied depending upon combinations of avirulent and virulent strains used. Furthermore, the suppression was exhibited only with living avirulent cells. Therefore, the mechanisms of the suppression of bacterial seedling rot by avirulent $\boldsymbol{P}$. glumae seem to be quite different from those of bacterial wilt of tomato. The competition for infection sites and nutrients seem to be involved in the mechanisms.

It has been reported that some pathogens lost their pathogenicity by mutation maintained without loosing their ability to colonize the niche, and invade to multiply in host tissues similarly to virulent strains ${ }^{1,9}$. If such an avirulent strain was applied first, the virulent strains will be prevented from effective access to infection sites. Other bacteria belonging to the genus Agrobacterium, Erwinia, Bacillus and Clavibacter did not show suppression at all.

Some strians of $\boldsymbol{P}$. glumae produce bacteriocins which inhibit growth of other strains of $P$. glumae. However, no correlation was observed between suppressiveness and bacteriocin productivity of avirulent strain or bacteriocin sensitivity of virulent strains (data not shown). Therefore, the mechanism of the difference in the suppressiveness depending upon combination of the avirulent and virulent strains is not clear at present. Supposedly, it might be due to the difference in compatibility of each avirulent and virulent strain to rice plants.

Of the five avirulent strains used, the strain N7503 constantly showed highest suppressive effect against all virulent strains. Avirulent strain N7503 may be rationally useful agent for biocontrol of bacterial seedling rot of rice. However, before practical application of this avirulent strain, those should be confirmed that the strain is strictly non-pathogenic to all host plants as well as to rice plant and that reverse mutation does not occur in natural conditions.

\section{Literature cited}

1. Averre, C.W., III and Kelman, A. (1964). Severity of bacterial wilt as influenced by ratio of virulent to avirulent cells of Pseudomonas solanacearum in inoculum. Phytopathology 54: 779-783.

2. Chen, W., Echandi, E. and Spurr, H.W., Jr. (1981). Protection of tobacco plants from bacterial wilt with avirulent bacteriocin-producing strains of Pseudomonas solanacearum. Proc. Fifth Int. Conf. Plant Path. Bact. Cali. 482-492.

3. Chen, W.Y. and Echandi, E. (1984). Effect of avirulent bacteriocin-producing strains of Pseudomonas solanacearum on the control of bacterial wilt of tobacco. Plant Pathol. 33: 245-253.

4. Furuya, N., Kushima, Y., Tsuchiya, K., Matsuyama, N. and Wakimoto, S. (1990). Protection 
of tomato seedlings by pre-treatment with Pseudomonas glumae from infection with Pseudomonas solanacearum and its mechanisms. Ann. Phytopath. Soc. Japan 57: 363-370.

5. Kerr, A. (1972). Biological control of crown gall: seed inoculation. J. Appl. Bacteriol. 35: 493497.

6. Kerr, A. and Htay, K. (1974). Biological control of crown gall through bacteriocin production. Physiol. Plant Pathol. 4: 37-44.

7. Goto, T. (1983). Effect of thiram seed protection on bacterial seedling rot of rice by Pseudomonas glumae. Ann. Rept. Plant Prot. North Japan 34: 107-108.

8. Mogi, S., Naito, H. and Tsushima, S. (1981). Effects of some chemical treatments on bacterial grain rot of rice. Proc. Assoc. Plant Protec. Kyushu 27: 9-11.

9. Trigalet, A. and Trigalet-Demery, D. (1990). Use of avirulent mutants of Pseudomonas solanacearum for the biological control of bacterial wilt of tomato plants. Physiol. Mol. Plant Pathol. 36: 27-38.

10. Uematsu, T., Yoshimura, D., Nishiyama, K., Ibaraki, T. and Fujii, H. (1976). Occurrence of bacterial seedling rot in nursery flat, caused by grain rot bacterium Pseudomonas glumae. Ann. Phytopath. Soc. Japan 42: 310-312.

11. Uematsu, T., Yoshimura, D., Nishiyama, K., Ibaraki, T. and Fujii, H. (1976). Pathogenic bacterium causing seedling rot of rice. Ann. Phytopath. Soc. Japan 42: 464-471.

12. Wakimoto, S., Hirayae, K., Tsuchiya, K., Kushima, Y., Furuya, N. and Matsuyama, N. (1986). Production of antibiotics by plant pathogenic pseudomonads. Ann. Phytopath. Soc. Japan 52: 835842.

13. Yasunaga, T., Matsumoto, H. and Shigematsu, Y. (1982). Effect of S-0208 wettable powder on bacterial grain rot of rice. Proc. Assoc. Plant Protec. Shikoku 17: 35-40.

\section{和 文 摘 要}

古屋成人・岡本知子・郡 裕一・松山宣明・脇本 哲 : 非病原性イネもみ枯細菌病菌によるイネ幼苗腐敗 症の発病抑制効果

非病原性のイネもみ枯細菌病菌株でイネ種子を処理することによりイネ幼苗腐敗症の発病が抑制された。 この発病抑制効果は，供試した非病原性菌株と病原性菌株の組合せにより異なり，また非病原性菌株の細菌 濃度が高いほど顕著であった。発病抑制効果は, イネもみ枯細菌病菌の生菌でのみ認められ，それ以外の 菌, すなわち, Agrobacterium, Erwinia, Bacillus, Clavibacter 等ではまったく認められなかった。供試した 非病原性 5 菌株のらち，N7503 は供試したすべての病原性菌株による発病を抑制し，その防除効果も高く， イネ幼苗腐敗症に対する生物的防除材としての利用の可能性が示唆された。 